\title{
ABUNDANCE AND FORAGING BEHAVIOR OF NATIVE INSECT POLLINATORS AND THEIR EFFECT ON MUSTARD (BRASSICA JUNCEA L.)
}

\author{
Eeshita Mandal, Md. Ruhul Amin*, Habibur Rahman \\ and Abdul Mannan Akanda ${ }^{1}$ \\ Department of Entomology, Bangabandhu Sheikh Mujibur Rahman \\ Agricultural University, Gazipur, Bangladesh
}

\begin{abstract}
A field experiment was carried out in Gazipur, Bangladesh to find out the abundance and behavior of native insect pollinators and their impact on the yield and seed quality of mustard (Brassica juncea L.). Total 8 species of insects under 8 different families in 3 orders were found as pollinator and their abundance ranged from 0.5 to $6.6 / 30$ sweeps. The pollinator insects revealed statistically higher abundance compared to pest, predator and other category. The pollinators were most abundant at $11.0 \mathrm{hrs}$ of the day and differed in their landing duration on flower. Ant and cabbage butterfly stayed statistically similar and longer time (24.1 and $23.5 \mathrm{sec}$., respectively). The highest yield (994.3 kg/ha) was obtained from insect managed pollination treatment followed by open $(759.7$ $\mathrm{kg} / \mathrm{ha})$ and enclosed condition $(272.3 \mathrm{~kg} / \mathrm{ha})$. Insect pollination revealed higher percentage of germination, t100-seed weight, per cent oil and protein content but the results did not differ statistically.
\end{abstract}

Key words: Insect abundance, Behavior, Brassica juncea, Crop yield, Seed quality

\section{INTRODUCTION}

Mustard (Brassica juncea L.) ranks first among the oil yielding crops in Bangladesh. It contains 44 to $46 \%$ oil and its meal has $38-40 \%$ protein having complete set of amino acids and low saturated fats (Das et al. 2009). Many insect species forage in the mustard field from seedling to harvesting stage of the crop. The foraging insects act as pest, predator, pollinator, and some has insignificant role. Roy et al. (2014) observed 24 insect species belonging to 14 families under 6 orders in mustard field during blooming period. They reported that four species were found as pollinator, 13 species as nectar collector and rest species were only visitors.

Honeybees are most important pollinating insect and they have been utilized to provide managed pollination in mustard field (Sharma et al. 2004, Klein et al. 2007). Other than honey bees, many insects in the order Diptera, Lepidoptera and Hymenoptera perform pollination in mustard and play significant role to improve fertilization, thus increase fruit set, viability of seed, seed yield, oil and

*Author for correspondence: <mramin.bsmrau@gmail.com>. 1Department of Plant Pathology, Bangabandhu Sheikh Mujibur Rahman Agricultural University, Gazipur, Bangladesh.

(c) 2018 Zoological Society of Bangladesh DOI: http://dx.doi.org/10.3329/bjz.v46i2.39045 
nutrient contents in the seed. On the contrary, usefulness of pollination networks act as a framework for ecological and evolutionary processes of flowering plants and lead to a patterns of biodiversity (Bascompte and Jordano 2007, Vasquez et al. 2009).

Pollination efficiency depends on abundance and diversity of insects and their foraging behavior. Mustard growers in Bangladesh are showing interest in honey bees for pollination of their crop but no study was performed on the behavior and role of the abundant insect pollinations. Study on this issue will be helpful for them as well as the improvement of national production, and will be of practical assistance to mustard growers and extension specialists worldwide.

\section{MATERIAL AND METHODS}

The study was conducted during September to December, 2016 in the Department of Entomology, Bangabandhu Sheikh Mujibur Rahman Agricultural University (BSMRAU), Gazipur, Bangladesh. A randomized complete block design comprising $4.0 \mathrm{~m} \times 4.0 \mathrm{~m}$ plots was used. The spacing between all blocks and plots was $60 \mathrm{~cm} \times 60 \mathrm{~cm}$. Seeds were sown in 9 plots on 5th September, 2016, in rows and distance from row to row was $45 \mathrm{~cm}$. Fertilizers were applied according to the fertilizer recommendation guide (FRG 2012). All the intercultural operations except insecticide application were done whenever necessary. Plants were covered with net (mesh size $3 \mathrm{~mm}$ ) for the whole duration of flowering in six plots to compare among seed set of enclosed flowers (wind pollination only), seed set of pollinators managed flowers (wind and provided insect only) and seed set of open flowers (wind and wild insect) treatments.

Free-living insects were collected from the open field during blooming period using a $30 \mathrm{~cm}$ diameter sweep net. Every week sweeping was done at 07, 09.00, 11.00 and 13.00 hour of the day, and each sample was consisted of 30 sweeps encompassing an area from ground level to the top of the plants. The collected insects were brought to the Entomology Laboratory of BSMRAU for counting. Landing duration of the pollinators on mustard flowers was measured using a stop watch and data were recorded 50 times for each species. Mature siliquae were harvested and seeds were weighed and the yield was expressed in $\mathrm{kg} / \mathrm{ha}$. Oil (total fat) and protein contents were measured in the Central Laboratory of Bangladesh Agricultural Research Institute, Gazipur by Soxlet oil extraction and modified Kjaldhal methods, respectively. Germination test was done following Amin et al. (2016).

One-way analysis of variance (ANOVA) followed by Tukey HSD posthoc test was used for analyzing abundance and landing duration of the insects, and yield of mustard. Germination, 1000-seed weight, oil and protein contents were 
analyzed by Chi $\left(\chi^{2}\right)$ statistic. All the analyses were performed using IBM SPSS 19.0 .

\section{RESULTS AND DISCUSSION}

Results shown in Table 1 indicated that 8 species of insects belonged to 8 different families in 3 orders namely Lepidoptera, Diptera and Hymenoptera were found as pollinator. Their abundance varied from $6.6 \pm 1.6$ to $0.5 \pm 0.3 / 30$ sweeps and the results differed significantly $\left(\mathrm{F}_{7,56}=2.66, \mathrm{p}<0.05\right)$. Among the pollinators, ensign fly and sweat bee showed statistically similar and higher abundance. Abundance of insect pollinators varied with geographic locations, cropping season and plant species. Kunjwal et al. (2014) studied the flowervisiting insect pollinators in brown mustard field at Patnagar in India and reported that 30 species of insects belonged to 10 families and 4 orders were found as pollinators. Amin et al. (2015) found 8 species of insects as pollinator in a mango-based agroforestry in Bangladesh, which belonged to Lepidoptera, Hymenoptera and Diptera and differed in their abundance.

Table 1. Insect pollinators along with their abundance in mustard field during October, 2016 to January, 2017

\begin{tabular}{llll}
\hline Pollinators & $\begin{array}{l}\text { Taxonomic } \\
\text { profile }\end{array}$ & $\begin{array}{l}\text { Number } \\
\text { of sweep }\end{array}$ & $\begin{array}{l}\text { Abundance } \\
\text { (Mean } \pm \mathrm{SE} \text { ) }\end{array}$ \\
\hline Syrphid fly & Syrphid sp. (Diptera: Syrphidae) & 30 & $1.3 \pm 0.5 \mathrm{c}$ \\
Honey bee & Apis mellifera (Hymenoptera: Apidae) & 30 & $4.9 \pm 1.8 \mathrm{ab}$ \\
Sweat bee & Halictus sp. (Hymenoptera: Halictidae) & 30 & $6.6 \pm 1.9 \mathrm{a}$ \\
House fly & Musca domestica (Diptera: Muscidae) & 30 & $4.5 \pm 1.1 \mathrm{ab}$ \\
Ensign fly & Sepsis fulgens (Diptera: Sepsidae) & 30 & $6.6 \pm 1.6 \mathrm{a}$ \\
Blow fly & Calliphora erythrocephala (Diptera: Calliphoridae) & 30 & $2.3 \pm 0.8 \mathrm{~b}$ \\
Cabbage butterfly & Pieris rapae (Lepidoptera: Pieridae) & 30 & $0.5 \pm 0.3 \mathrm{~d}$ \\
Ant & Camponotus compressus (Hymenoptera: & 30 & $2.5 \pm 0.3 \mathrm{~b}$ \\
& Formicidae) & & \\
\hline
\end{tabular}

Means in the column followed by same letter(s) are not significantly different by Tukey posthoc statistic at $<0.05$.

Abundance of the different categories of insects during full blooming period ranged from $1.0 \pm 0.4$ to $44.2 \pm 6.6 / 30$ sweeps and the results differed significantly (Fig 1: $\mathrm{F}_{3,16}=37.7 ; \mathrm{p}<0.001$ ). The pollinators exerted the highest abundance and the other three categories revealed statistically identical results. It is evident that the mustard flower is a good source of nectar, which attracted the insects for foraging. That is why the number of pollinators was higher than other categories of insects. 
The number of insects visited in the mustard field at different hours of the day varied from $25.0 \pm 2.7$ to $49.8 \pm 4.9 / 30$ sweeps and the results differed significantly (Fig. $2: \mathrm{F}_{3,16}=8.9, \mathrm{p}<0.01$ ). Insects were most abundant at 11.0 hour of the day. At that time most of the flowers opened and the air temperature and light intensity were sufficient for the activity of the pollinators. The present study showed accordance with Amin et al. (2015) who observed peak foraging activity of the pollinators in a mango-based agroforestry at 11.0 hour of the day when the mango flowers opened. Goyal et al. (1989) observed peak foraging activity of syrphid fly, house fly and honeybee at 10.0 - $11.0 \mathrm{hrs}$ of the day on carrot. Ahmad and Aslam (2002) studied the foraging behavior of some Hymenoptera, Diptera, Coleoptera and Lepidoptera pollinators on blooming carrot and found peak foraging at $8.0-9.0 \mathrm{hrs}$ of the day.

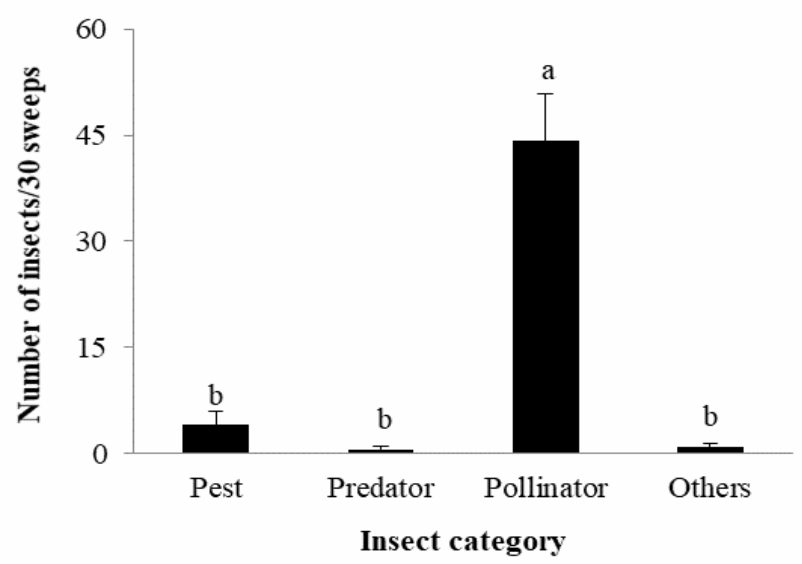

Fig. 1. Abundance (mean $\pm \mathrm{SE}$ ) of different categories of insects in the mustard field during full blooming period. Bars with common letter(s) are not significantly different by Tukey posthoc statistic at $\mathrm{p}<0.05$.

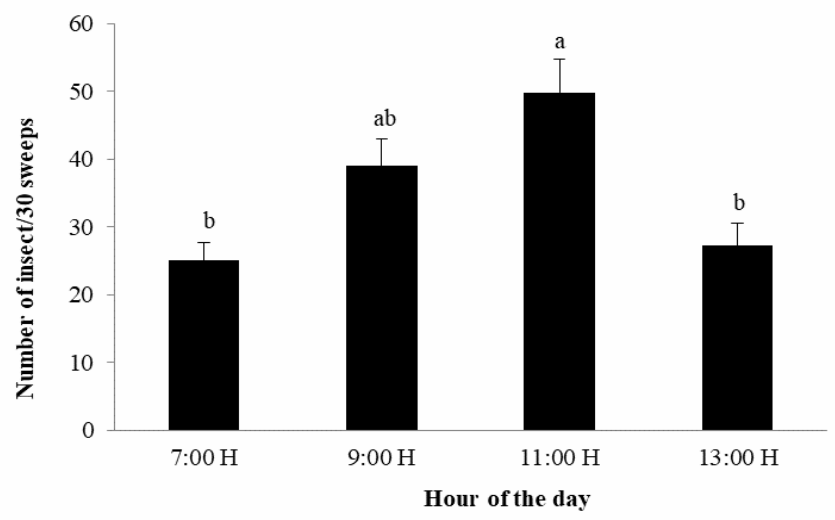

Fig. 2. Abundance of insects (mean $\pm \mathrm{SE}$ ) in the mustard field at different hours of the day during full blooming period. Bars with common letter(s) are not significantly different by Tukey posthoc statistic at $\mathrm{p}<0.05$. 
Pollinator species differed in their landing duration on the flowers and their activity led to higher levels of fruit set. In the present study, landing duration of the pollinators ranged from $12.9 \pm 1.1$ to $24.1 \pm 2.2 \mathrm{sec} /$ flower and the results differed significantly (Fig. 3: $F_{5,294}=7.3$; $p<0.01$ ). Results showed that the ants and cabbage butterfly spent statistically similar and longer duration, and house fly took the shortest time. Flower visitation time of insect not only depend on their species but also on crops. Saeed et al. (2008) reported that the syrphid flies were the rapid visitors on loquat flowers. Amin et al. (2015) found that the syrphid fly spent shortest duration, and horse fly and sulphur butterfly spent statistically similar and longer duration on mango flower.

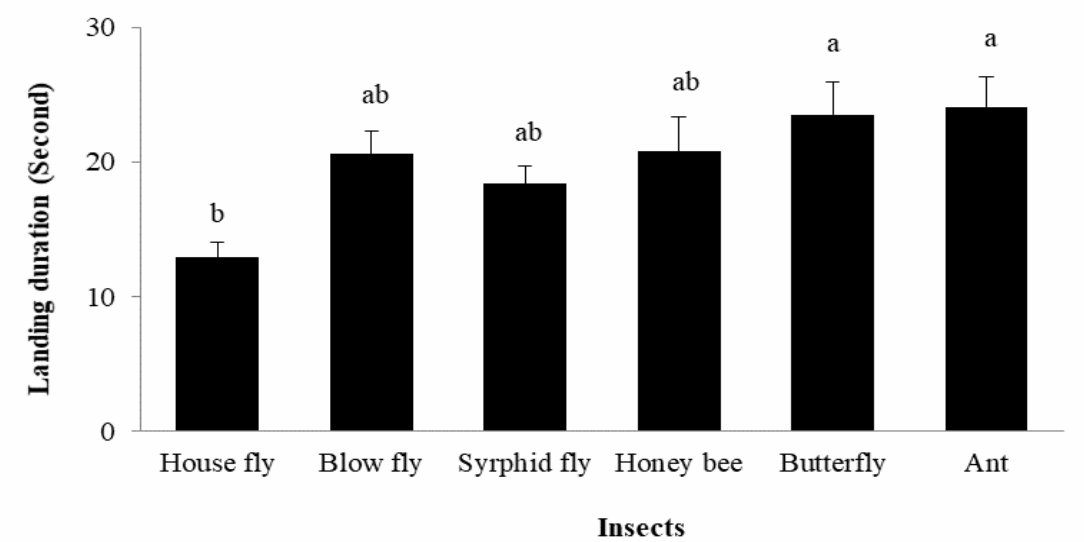

Fig. 3. Landing duration (mean $\pm \mathrm{SE}$ ) of different insect pollinators associated with mustard flowers. Bars with common letter(s) are not significantly different by Tukey posthoc statistic at $\mathrm{p}<$ 0.05 .

The present study showed that the insect pollination had significant effect on the yield of mustard (Fig. 4: $F_{2,6}=397.9,<0.001$ ). The highest yield $(994.3$ $\mathrm{kg} / \mathrm{ha}$ ) was obtained from managed pollination condition followed by natural pollination $(759.7 \mathrm{~kg} / \mathrm{ha})$ and the lowest yield was obtained from the enclosed condition $(272.3 \mathrm{~kg} / \mathrm{ha})$. The present findings showed agreement with Gebremedhn and Tadesse (2014) who obtained higher yield of Guizotia abyssinica from crops caged with honeybees compared to insect excluded pollination condition.

Table 2 showed that the germination of seed, 1000-seed weight, oil and protein content in seeds among the treatments varied from 88.0 to $92.0 \%, 2.4$ to $2.9 \mathrm{~g}, 39.6$ to $42.6 \%$ and 21.5 to $22,3 \%$, respectively, and the results did not differ significantly (germination: $\chi^{2}=0.09, \mathrm{df}=2, \mathrm{p}=0.96 ; 1000$-seed weight: $\mathrm{x}^{2}$ $=0.25, \mathrm{df}=2, \mathrm{p}=0.9$; oil content: $\chi^{2}=0.11, \mathrm{df}=2, \mathrm{p}=0.94 ;$ protein content: $\mathrm{x}^{2}$ $=0.0$, df $=2, \mathrm{p}=1.00$ ). Pudasaini et al. (2014) found higher percentage of 
germination and thousand seed weight, and oil content in rapeseed in the Apis cerana pollinated treatment followed by Apis mellifera, and lowest in control (enclosed plot). Insect pollination elucidated higher yield in managed condition because the flowers were pollinated in the phase of fully functional and generative organs.

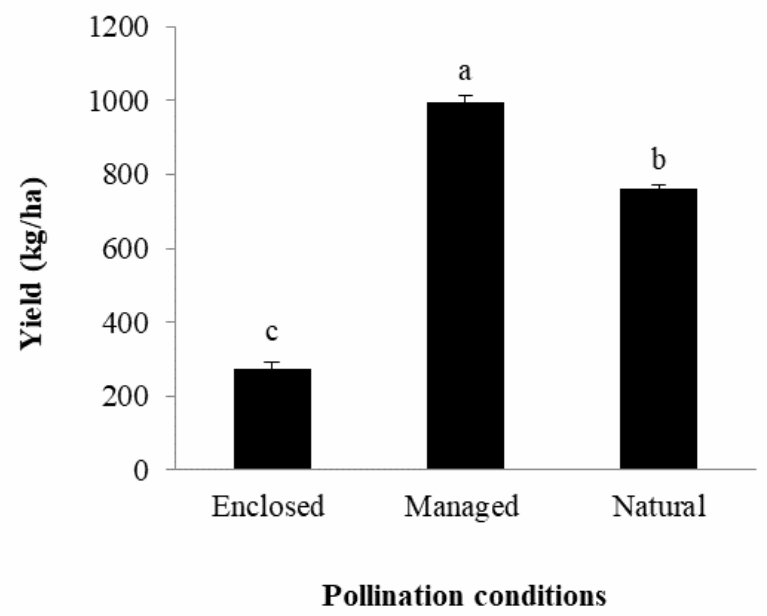

Figure 4. Effect of different pollination conditions on the yield (mean $\pm \mathrm{SE}$ ) of mustard. Bars with common letter(s) are not significantly different by Tukey posthoc statistic at $\mathrm{p}<0.05$.

Table 2. Effect of different pollination conditions on quality attributes of mustard seed.

\begin{tabular}{lcccc}
\hline Pollination conditions & $\begin{array}{c}\text { Germination } \\
(\%)\end{array}$ & $\begin{array}{c}\text { Thousand seed } \\
\text { wt. (g) }\end{array}$ & $\begin{array}{c}\text { Oil content } \\
(\%)\end{array}$ & $\begin{array}{c}\text { Protein } \\
\text { content (\%) }\end{array}$ \\
\hline Enclosed & 88 & 2.4 & 39.6 & 22.3 \\
Managed & 92 & 2.9 & 42.6 & 21.5 \\
Open & 90 & 2.8 & 41.5 & 22.2 \\
\hline
\end{tabular}

The present study depicted that the pollinator insects led to higher abundance compared to pest, predator and other category. The mustard yields were improved with insect pollination, and the plants in the natural condition also received sufficient pollination services by insects. To maintain native insect pollination services in Bangladesh, efforts should be made for their conservation through proper habitat management.

\section{LITERATURE CITED}

AHMAD, M. and ASLAM, M. 2002. Pollinators visiting carrot (Daucus carota L.) seed crop. J. Res. Sci. 13: 31-35.

AMIN, M.R., AFRIN, R., SUH, S.J. and KWON, Y.J. 2016. Infestation of sucking insect pests on five cotton cultivars and their impacts on varietal agronomic traits, biochemical contents, yield and quality. SAARC J. Agric. 14: 11-23. 
AMIN, M.R., NAMNI, S., MIAH, M.R.U., MIAH, M.G., ZAKARIA, M., SUH, S.J. and KWON, Y.J. 2015. Insect inventories in a mango-based agroforestry area in Bangladesh: foraging behavior and performance of pollinators on fruit set. Ent. Res. 45: 217-224.

BASCOMPTE, J. and JORDANO, P. 2007. Plant-animal mutualistic networks: the architecture of biodiversity. Ann. Rev. Ecol. Evol. Syst. 38: 567-593.

DAS, M., WILEY, D.J., CHEN, X., SHAH, K. and VERDE, F. 2009. The conserved NDR kinase orb6 controls polarized cell growth by spatial regulation of the small GTPase Cdc42. Current Biol. 19: 1314-1319.

FRG. 2012. Fertilizer Recommendation Guide. Bangladesh Agricultural Research Council, Farm Gate, Dhaka.

GEBREMEDHN, H. and TADESSE, A. 2014. Effect of honeybee (Apis mellifera) pollination on seed yield and yield parameters of Guizotia abyssinica (L.F.). Indian J. Agril. Sci. 9: 3687-3691.

GOYAL, N.P., SINGH, M. and KANDORIA, J.L. 1989. Role of intercropping in seed quality of tomato. Indian J. Agril. Sci. 51: 89-93.

KLEIN, A.M., VAISSIÈRE, B., CANE, J.H., STEFFAN-DEWENTER, I., CUNNINGHAM, S.A. and KREMEN, C. 2007. Importance of crop pollinators in changing landscapes for world crops. Proc. Royal Soc. Biol. Sci. 274: 303-13.

KUNJWAL, N., KUMAR, Y. and KHAN, M.S. 2014. Flower-visiting insect pollinators of brown mustard, Brassica juncea (L.) Czern and Coss and their foraging behavior under caged and open pollination. African J. Agril. Res. 9: 1278- 1286.

PUDASAINI, R., THAPA, R.B. and POUDEL, P.R. 2014. Effect of pollination on qualitative characteristics of rapeseed (Brassica campestris L. var. toria) seed in Chitwan, Nepal. Intl. Schol. Sci. Res. Innov. 8: 1403-1406.

ROY, S., GAYEN, A.K., MITRA, B. and DUTTAGUPTA, A. 2014. Diversity, foraging activities of the insect visitors of mustard (Brassica juncea L,) and their role in pollination in West Bengal. $J$. Zool. Stud. 1: 7-12.

SAEED, S., KWON, O. and KWON, Y.J. 2008. Fidelity of Hymenoptera and Diptera pollinators in onion pollination. Ent. Res. 38: 276-280.

SHARMA, S., SOMMERS, J.A., WU, L., BOHR, V.A., HICKSON, I.D. and BROSH, R.M. 2004. Stimulation of flap endonuclease- 1 by the Bloom's syndrome protein. J. Biol. Chem. 279: 98479856.

VASQUEZ, D.P., BLUTHGEN, N., CAGNOLO, L. and CHACOFF, N.P. 2009. Uniting pattern and process in plant-animal mutualistic networks: a review. Ann. Bot. 103: 1445- 1457. 